\title{
Teachers' Organizational Communication and Their Job Motivation
}

\author{
Öznur Ataş Akdemir ${ }^{1}$ \\ ${ }^{1}$ Faculty of Education, Firat University, Elazığ, Turkey \\ Correspondence: Öznur Ataş Akdemir, Faculty of Education, Frrat University, Elazı̆̆g, Turkey. E-mail: \\ oznuratasakdemir@gmail.com
}

Received: February 26, 2019

Accepted: March 15, 2019 Online Published: March 19, 2019

doi:10.5539/jel.v8n2p264

URL: https://doi.org/10.5539/jel.v8n2p264

\begin{abstract}
The purpose of this study is to determine the effect of teachers' organizational communication on their job motivation. The research model is correlational survey model. The participants of the study are 111 teachers working at public elementary schools in Turkey. Organizational Communication Scale and Job Motivation Scale are used as data collection instruments. For data analysis, Pearson correlation analysis and basic linear regression analysis are applied with SPSS. The findings of the study showed that teachers' organizational communication and job motivation levels are at high level. Also, it is determined that there is a positive, high and significant relationship between teachers' organizational communication and their job motivation. Besides, teachers' organizational communication significantly predicts their job motivation. The findings of this study are discussed with related researches and some suggestions are presented.
\end{abstract}

Keywords: teachers, organizational communication, job motivation

\section{Introduction}

\subsection{Organizational Communication}

The definition of organization highlights its functional structure of being formed by people who have come together for shared targets or for mutual or common aims. Organizations exist with people who are organized, in other words who have come together, for common or shared work plans, workforce or duties. People convey a number of verbal or non-verbal communicative processes while they are working in an organization. Thus, communication, one of the basic features of human being, is quite important for organizations. Downs and Adrian (2012) point out that communication affects the productivity of an organization. Organizational communication is defined as an exchange of idea and information in an organization (Bovee, Thill, \& Schatzman, 2003). According to Akat, Budak and Budak (2002), organizational communication is a social process which enables setting relationships between organization and its environment as well as exchanging ideas and information between the sections of an organization. Daft (1997) points that organizational communication includes the process of comprehension as well as conveying verbal and non-verbal messages. De Nobile and McCormick (2008) define organization communication as 'the process whereby people within an organization give and receive messages' (p. 102). They elaborate the definition with explaining the ways of organizational communication as being 'messages moving upward and downward between hierarchical levels and horizontally among people at the same level' (p. 102).

Organizational communication can be in formal or informal way (Goebel, Marshall, \& Locander, 2004). These two types of organizational communication have different natures and roles. Formal communication is a hierarchical way of conveying the official information in the structure. It can be top-down, bottom-up, horizontal or vertical depending on the importance and sort of the messages conveyed. Informal communication is, on the other hand, conducted by mostly personal relationships and without formal rules. Though being mostly verbal, it can also be in written forms. Informal communication has a role of facilitating conveying the formal messages and enhancing the unity of the organization. However, grapevines are among the most common type of informal communication which can be harmful for the relationships among the members of an organization (Bakan \& Büyükbeşe, 2004; De Nobile \& McCormick, 2008; Karcıŏlu, Timuroğlu, \& Çınar, 2009).

De Nobile and McCormick (2008) define four functional traits of organization communication. These are directive, supportive, cultural and democratic communication. A message can serve various functions. For example, a school meeting can convey directive and as supportive communication for teachers. 
There are numerous studies in the literature on the relationship between organizational communication and organizational identification (Çanak \& Avc1, 2016); job satisfaction (Yüksel, 2005); labors' management of expressing their emotions (Eroğlu, 2010); and organizational citizenship (Uslu \& Balc1, 2012).

\subsection{Job Motivation}

Motivation, a recently popular concept for social sciences, has its roots in Maslow's hierarchy of needs. Relevant literature is full of definitions of motivation (Arifin, 2015; Kearney, 2018; Lazaroiu, 2015; Skaalvik \& Skaalvik, 2018). A simple definition can be 'a drive to do something'. Regarding Maslow's pyramid model, when a human being desires to get one more step for his/her needs, this a beginning point of being motivated to do something. A more comprehensive definition of motivation is given by Timuroğlu and Balkaya (2016) as follows: Motivation is a set of internal or external drives directing a person to a target or enabling a person to act towards a desired goal; or enabling him/her sustain the action to reach a desired goal. There are two types of motivation regarding its source: internal and external motivation. Sense of responsibility, success, personal development or self-fulfillment are the main factors of internal motivation. Internal motivation is identified with being voluntary for a job. The factors of external motivation are wage, salary or other financial expectations, promotion, desire of being appreciated by the employer. Job motivation is internal or external incentive of a person in an organization. This incentive enables the person to hold persistence to overcome the difficulties as well as encouraging to reach the goals. There is no doubt that job motivation has a positive effect on job performance and personal accomplishment level (Tentama \& Pranungsari, 2016). There are several studies which aimed to explore the relationship between job motivation and decision making levels of teachers (Özdoğru \& Aydın, 2012); job satisfaction (Bishay, 1996); school leadership and reactions to policies (Leithwood, Steinbach, \& Jantzi, 2002); school based performance awards (Kelley, Heneman, \& Milanowski, 2002); burnout (Anderson \& Iwanicki, 1984); school based variables (Ayaydın \& Tok, 2015); and organizational commitment (Oran, Güler, \& Bilir, 2016).

Based on the theory of Barnard (1938) which suggest that personal motivation leads authentic communication enabling the continuity of communication, $\mathrm{Lu}$ (2003) points that motivation has a positive effect on informal organizational communication, thus, organizational communication should be regarded as a key concept. Research on investigating the effect of positive communication in increasing motivation has focused on call centers (Özkan, 2013), banking (Yoo, Flaherty, \& Frankwick, 2014), and nurses and other health employees (Cherry, Ashcraft, \& Owen, 2007; Timuroğlu \& Balkaya, 2016).

Studies on teachers' job motivations and organizational communication is rather limited (Özgan \& Aslan, 2008; Park \& Rainey, 2012). Most of the studies have been devoted to explore the relationship between teachers' job motivations and organizational commitment, job satisfaction and leadership styles (Arifin, 2015; Girma, 2016; Terek et al., 2015).

\subsection{Purpose of the Study}

Current study is expected to shed light on the relationship between teachers' job motivation and organizational communication. This research targets to investigate the effects of teachers' organizational communication on their job motivation. For this reason, following questions are tried to be answered in this study:

a) What are the levels of teachers' organizational communication and job motivation?

b) Is there any relationship between teachers' organizational communication and job motivation?

c) Do teachers' organizational communication significantly predict their job motivation?

\section{Method}

\subsection{Research Model}

In the present study, it is aimed to determine the effects of teachers' organizational communication on their job motivation by examining the relationship between teachers' organizational communication and their job motivation. For this purpose, correlational survey model is used.

\subsection{Participants}

One hundred eleven teachers who are working at public primary schools in one of the provinces of Turkey are recruited for this study. The gender distribution of the participants consists of $72(64.9 \%)$ female and $39(35.1 \%)$ male. In terms of teachers' professional degree, $23(20.7 \%)$ of whom have $1-5$ years seniority, $28(25.2 \%)$ of whom have 6-10 years seniority, 32 (28.8\%) of whom have 11-15 years seniority, $20(18 \%)$ of whom have 1620 years seniority, $8(7.2 \%)$ of whom have 21 years and more seniority. Additionally, $99(89.2 \%)$ of teachers are B.A. holders and $12(10.8 \%)$ of them are holding a graduate degree. 


\subsection{Data Collection Instruments}

In this study, Organizational Communication Scale is used for collecting data to determine the teachers' organizational communication levels and Job Motivation Scale is used for collecting data to determine the teachers' job motivation levels.

\subsubsection{Organizational Communication Scale}

In order to determine the level of teachers' organizational communication level, Organizational Communication Scale which is developed by Celep (2000) and reliability and validity analysis conducted by Erel Yetim (2010) is used. This scale is composed of 34 items with five Likert-type grades. It includes four sub dimensions which are called as task-oriented communication, informative communication, feedback and communication towards attitude and behavior. In this research, it is found that Cronbach alpha reliability coefficient that belongs to scale is .99 . On the other hand, Cronbach alpha reliability coefficient that belongs to dimensions is found that reliability coefficient for task-oriented communication is .93 , reliability coefficient for informative communication is .97 , reliability coefficient for feedback is .95 and reliability coefficient for communication towards attitude and behavior is .97 .

\subsubsection{Job Motivation Scale}

To determine the level of teachers' job motivation level, Job Motivation Scale that is developed by Aksoy (2006) and adapted to educational organizations by Tanriverdi (2007) is used. This scale is composed of 18 items with five Likert-type grades. This scale is a unidimensional. Cronbach alpha coefficient of the scale is found .98 .

\subsection{Data Analysis}

In the analysis of data gathered for the present study, mean, standard deviation, frequency, and percentage, correlation analysis, simple and multiple linear regression analysis are used. Before correlation analysis and regression analysis between the variations are carried out, analysis of missing data and outliers are handled, normality, linearity and the problem of multicollinearity are examined. To test whether the set of data is normally distributed, coefficient of kurtosis and coefficient of skewness are employed. In the present study, the coefficient of skewness of the organizational communication is found as -0.72. In terms of sub dimensions of organizational communication, the coefficient of skewness is found as -0.99 for task-oriented communication, -0.79 for informative communication, -0.85 for feedback and -0.78 for communication towards attitude and behavior. Additionally, the coefficient of kurtosis of the organizational communication is found as -0.19 . On the other hand, the coefficient of kurtosis regarding sub dimensions of organizational communication is found as 0.49 for task-oriented communication, -0.05 for informative communication, -0.02 for feedback and -0.29 for communication towards attitude and behavior.

When coefficient of skewness regarding job motivation is checked, it is found as -0.60 . Addition to these statistical data, the coefficient of kurtosis regarding job motivation is found as -0.74 . According to these findings, the data can be accepted as normally distributed. To determine whether there is multicollinearity problem between variables, the binary correlation between independent variables and dependent variables are investigated and it is found that the variables aren't too highly correlated to create problems related to multicollinearity.

\section{Results}

Descriptive statistics related to variables of the present study and the relationships between these variables are shown in Table 1.

Table 1. Mean and standard deviation of variables and relationships between organizational communication and job motivation

\begin{tabular}{lllllllll}
\hline Variables & $\mathrm{M}$ & $\mathrm{Sd}$ & 1 & $1 \mathrm{a}$ & $1 \mathrm{~b}$ & $1 \mathrm{c}$ & $1 \mathrm{~d}$ & 2 \\
\hline 1.Organizational Communication & 4.13 & .89 & - & & & & & \\
1a. Task Oriented Communication & 4.14 & .93 & $.94^{* *}$ & - & & & \\
1b. Informative Communication & 4.10 & .93 & $.98^{* *}$ & $.92^{* *}$ & - & & \\
1c. Feedback & 4.14 & .91 & $.96^{* *}$ & $.85^{* *}$ & $.91^{* *}$ & - & & \\
1d. Com. towards at. and beh. & 4.13 & .92 & $.97^{* *}$ & $.86^{* *}$ & $.91^{* *}$ & $.91^{* *}$ & - \\
2. Job Motivation & 4.11 & .90 & $.81^{* *}$ & $.76^{* *}$ & $.77^{* *}$ & $.77^{* *}$ & $.82^{* *}-$ \\
\hline
\end{tabular}

Note. ${ }^{* *} \mathrm{p}<.01 ;{ }^{*} \mathrm{p}<.05$. 
As Table 1 shows that according to teachers' perceptions, the distributions related to organizational communication and job motivation are investigated and the following results are found. Teacher perceptions related to organizational communication and job motivation are found at high level. In terms of sub dimension of organizational communication, the highest mean belongs to task-oriented communication and feedback $(\mathrm{M}=4.14)$ while the lowest mean belongs to informative communication $(\mathrm{M}=4.10)$.

When the correlation coefficients between variables are investigated, it is clear that there is a positive, high level and significant relationship between organizational communication and job motivation $(\mathrm{r}=.81, \mathrm{p}<.01)$. Furthermore, there is significantly a positive and high-level relationship between sub dimensions of organizational communication and job motivation. These relationships are between job motivation and task-oriented communication $(\mathrm{r}=.76, \mathrm{p}<.01)$, informative communication $(\mathrm{r}=.77, \mathrm{p}<.01)$, feedback $(\mathrm{r}=.77, \mathrm{p}<.01)$, communication towards attitude and behavior $(\mathrm{r}=.82, \mathrm{p}<.01)$.

The findings related to organizational communication in the prediction of job motivation are given in Table 2 .

Table 2. The results of simple linear regression analysis regarding organizational communication in the prediction of job motivation

\begin{tabular}{llllll}
\hline Variables & B & S.E. & $\beta$ & $\mathrm{t}$ & $\mathrm{p}$ \\
\hline Constant & .71 & .24 & - & 2.96 & 0.00 \\
Organizational Communication & .82 & .06 & .81 & 14.48 & 0.00 \\
\hline
\end{tabular}

Note. $\mathrm{R}=0.81, \mathrm{R} 2=0.66, \mathrm{~F}=209.77, \mathrm{P}=0.000$.

As shown in Table 5, according to the perceptions of teachers, there is a significant relationship between organizational communication and job motivation $\left(\mathrm{R}=0.81, \mathrm{R}^{2}=0.66, \mathrm{p}<0.01\right)$. The predictive power of organizational communication for job motivation is found statistically significant and organizational communication explains the variance of job motivation at level of $66 \%$.

\section{Conclusion, Discussion and Recommendations}

The aim of this paper is to determine the effects of teachers' organizational communication on their job motivation by examining the relationship between teachers' organizational communication and their job motivation levels. The results of the present study indicate that there is a positive, high level and significant relationship between teachers' organizational and their job motivation. Additionally, teachers' perceptions regarding organizational communication play a significant role as a predictor of teachers' perceptions regarding job motivation.

When the results of the research are examined, it is found that teachers' organizational communication level is high and they show the highest level of organizational communication in task-oriented communication and feedback dimensions. Also, they show the lowest level of organizational communication in informative communication. This finding shows that teachers communicate with their colleagues mostly on job-related topics; and they give feedback to their workfellows. This finding is supported by the findings of previous studies as it proves that organizational communication effects several other factors and employees' organizational communication is at a high level (Chen, Silverthorne, \& Hung, 2005; Çanak \& Avc1, 2016; Eroğluer, 2011; Nobile \& McCormick, 2008; Uslu \& Balc1, 2012; Yıldız, 2013; Yüksel, 2005). Chen, Silverthorne and Hung (2005) have determined that high level of organizational communication leads to organizational commitment and job performance. Çanak and Avcı (2016), in a study in which they investigated the relationship between organizational identification and organizational communication, have found teachers' organizational communication level above average. Eroğluer (2011) conducted a study to explore the relationship between organizational communication and job satisfaction and discovered that employees have a good level of communication with their workfellows and administrators. Nobile and McCormick (2008) stated that organizational communication is a predictor of job satisfaction. Uslu and Balc1 (2012) have determined a positive and weak relationship between organizational communication and organizational citizenship. Yildiz (2013), in a study to explore the relationship between organizational communication and organizational identification, have found that teachers' communication levels towards task is higher. Yüksel (2005) also found that there is a strong relationship between communication and job satisfaction; and communication increases job satisfaction.

According to another finding of the study, teachers' job motivation is at a high level. Teachers who have a high level of job motivation do their job willingly and they become more productive in their jobs. Teachers' high level 
of motivation contributes students' academic success. On the other hand, teachers' lack of motivation has negative effects on teaching quality (Davidson, 2007). Studies on job motivation have shown that motivation effects several organizational behaviours; the findings of the current study are supported by the relevant literature (Argon \& Ertürk, 2013; Ayaydın \& Tok, 2015; Bishay, 1996; Eyal \& Roth, 2011; Karaköse \& Kocabaş, 2006; Oran, Güler, \& Bilir, 2016; Özdoğru \& Aydın, 2012). Argon and Ertürk (2013), in their study to determine the relationship between teachers' internal motivation and their perceptions towards organizational identity, have stated that teachers' internal motivation is at high level. Ayaydın and Tok (2015), in a research study to explore the factors effecting motivation, have found that the most important factor effecting teachers' motivation is teachers' willingness towards their job. Bishay (1996) conducted a study to determine the relationship between teachers' motivation and their job satisfaction; and found that teachers' motivation level is high and it is meaningfully related with their job satisfaction. Eyal and Roth (2011), in their study to review the relationship between teachers' motivation levels and school principals' leadership, have determined that school principals' leadership styles have an important effect on teachers' motivation levels and their well-being. Karaköse and Kocabaş (2006) in their qualitative research, in which they studied the effects of teacher expectations on job satisfaction and motivation, have concluded that, at private schools, principals' attitudes and behaviors have effect on teachers to motivate on their jobs. Oran, Güler and Bilir (2016) have determined that teachers' internal motivation is higher than their external motivation. Özdoğru and Aydın (2012), in their study to investigate teachers' decision-making situations and their motivations, have stated that teachers' motivation is at high level.

Lastly, it is found that the relationship between teachers' organizational communication levels and their job motivation is at a high and meaningful level in the current study. In other words, as teachers' organizational communication levels increase their job motivation also increases. Besides, teachers' organizational communication predicts their job motivation at a meaningful level. Based on these findings it can be said that organizational communication has an important role on motivation. Relevant studies on investigating the relationship between organizational communication and job motivation have found similar results (Özgan \& Aslan, 2008; Park \& Rainey, 2012; Timuroğlu \& Balkaya, 2016). Özgan and Aslan (2008), in their qualitative study aimed to determine the effects of school principals' verbal communication styles on teachers' motivation, have concluded that school principals' verbal communication styles effect teachers' motivation. Park and Rainey (2012) have determined that there is a meaningful relationship between job motivation and social communication. Timuroğlu and Balkaya (2016) have conducted a research on nurses, they have found that nurses' there is a positive and meaningful relationship between organizational communication and job motivation.

The results of the study have revealed that organizational communication has a high-level effect on teachers' job motivation. In this aspect, the following suggestions are listed in the light of the results of the present study: Panel and seminars on communication and motivation should be organized for teachers. Various social activities are suggested to be organized by school principals to develop and enhance organizational communication at school settings.

\section{References}

Akat, İ., Budak, G., \& Budak, G. (2002). İşletme Yönetimi. İzmir: Barış Yayınları.

Aksoy, H. (2006). Örgüt ikliminin motivasyon üzerine etkisi. Yayınlanmamış Yüksek Lisans Tezi, Marmara Üniversitesi Sosyal Bilimler Enstitüsü, İstanbul.

Anderson, M. B. G., \& Iwanicki, E. F. (1984). Teacher motivation and its relationship to burnout. Educational Administration Quarterly, 20(2), 109-132. https://doi.org/10.1177/0013161X84020002007

Argon, T., \& Ertürk, R. (2013). İlköğretim okulu öğretmenlerinin içsel motivasyonları ve örgütsel kimliğe yönelik algıları. Kuram ve Uygulamada Eğitim Yönetimi Dergisi, 19(2), 159-179.

Arifin, H. M. (2015). The influence of competence, motivation, and organisational culture to high school teacher job satisfaction and performance. International Education Studies, 8(1), 38-45.

Ayaydın, M., \& Tok, H. (2015). Motivasyonu etkileyen faktörlere ilişkin sınıf öğretmenlerinin görüşlerinin incelenmesi (Gaziantep örneği). Electronic Turkish Studies, 10(11), 187-200. https://doi.org/10.7827/TurkishStudies.8530

Bakan, İ., \& Büyükbeşe, T. (2004). Örgütsel iletişim ile iş tatmini unsurları arasındaki ilişkiler: Akademik örgütler için bir alan araştırması. Akdeniz IIIBF Dergisi, 7, 1-30.

Barnard, C. I. (1938). The functions of the executive. Cambridge, MA: Harvard. 
Bishay, A. (1996). Teacher motivation and job satisfaction: A study employing the experience sampling method. Journal of Undergraduate Sciences, 3, 147-154.

Bovee, C. L., Thill, J. V., \& Schatzman, B. E. (2003). Business communication today. Upper Saddle, NJ: Prentice Hall.

Celep, C. (2000). Eğitimde örgütsel adanma ve ögrretmenler. Ankara: Anı Yayınc1lı.

Chen, J. C., Silverthorne, C., \& Hung, J. Y. (2006). Organization communication, job stress, organizational commitment, and job performance of accounting professionals in Taiwan and America. Leadership \& Organization Development Journal, 27(4), 242-249. https://doi.org/10.1108/01437730610666000

Cherry, B., Ashcraft, A., \& Owen, D. (2007). Perceptions of job satisfaction and the regulatory environment among nurse aides and charge nurses in long-term care. Geriatric Nursing, 28(3), 183-192. https://doi.org/10.1016/j.gerinurse.2007.01.015

Çanak, M., \& Avc1, Ö. Y. (2016). Öğretmenlerin örgütsel özdeşleşme ve örgütsel iletişim düzeylerinin incelenmesi. Uluslararası Eğitim Bilimleri Dergisi, 7, 91-110.

Daft, R. L. (1997). Management. Fort Worth : Dryden Press.

Davidson, E. (2007) The pivotal role of teacher motivation in Tanzanian education. The Educational Forum, 71(2), 157-166. https://doi.org/10.1080/00131720708984928

De Nobile, J. J., \& McCormick, J. (2008). Organizational communication and job satisfaction in Australian Catholic primary schools. Educational Management Administration \& Leadership, 36(1), 101-122. https://doi.org/10.1177/1741143207084063

Downs, C. W., \& Adrian, A. D. (2012). Assessing organizational communication: Strategic communication audits. Guilford Press.

Erel Yetim, A. E. (2010). Genel liselerde örgütsel iletişsim ile örgütsel özdeşleşme arasındaki ilişski. Yayımlanmamış Yüksek Lisans Tezi, Gazi Üniversitesi Eğitim Bilimleri Enstitüsü, Ankara.

Eroğlu, E. (2010). Örgütsel iletişimin işgörenlerin duygu gösterimlerinin yönetimine olan etkisi. Selçuk Illetişim Dergisi, 6(3), 18-33.

Eroğluer, K. (2011). Örgütsel iletişim ile iş tatmini unsurları arasındaki ilişkiler: Kuramsal bir inceleme. Ege Akademik Bakış Dergisi, 11(1), 121-136.

Eyal, O., \& Roth, G. (2011). Principals' leadership and teachers' motivation: Self-determination theory analysis. Journal of Educational Administration, 49(3), 256-275. https://doi.org/10.1108/09578231111129055

Girma, S. (2016). The relationship between leadership style, job satisfaction and culture of the organization. International Journal of Applied Research, 2(4), 35-45.

Goebel, D. J., Marshall, G. W., \& Locander, W. B. (2004). An organizational communication - based model of individual customer orientation of nonmarketing members of a firm. Journal of Strategic Marketing, 12(1), 29-56. https://doi.org/10.1080/0965254032000171609

Karaköse, T., \& Kocabaş, İ. (2006). The effect of teachers' expectations on job satisfaction and motivation in private and public schools. Journal of Theory and Practice in Education, 2(1), 3-14.

Karcıoğlu, F., Timuroğlu, K., \& Çınar, O. (2009). Örgütsel iletişim ve iş tatmini ilişkisi - bir uygulama. İstanbul Üniversitesi İsletme İktisadi Enstitüsü Dergisi-Yönetim, 63, 59-76.

Kearney, R. (2018). Public sector performance: Management, motivation, and measurement. Routledge. https://doi.org/10.4324/9780429497964

Kelley, C., Heneman III, H., \& Milanowski, A. (2002). Teacher motivation and school-based performance $\begin{array}{llll}\text { awards. } & \text { Educational } & \text { Administration }\end{array}$ https://doi.org/10.1177/0013161X02383004

Lazaroiu, G. (2015). Employee motivation and job performance. Linguistic and Philosophical Investigations, 14, 97.

Leithwood, K., Steinbach, R., \& Jantzi, D. (2002). School leadership and teachers' motivation to implement accountability policies. Educational Administration Quarterly, 38(1), 94-119.

$\mathrm{Lu}, \mathrm{X}$. (2003). Public secrets as a phenomenon in organizational communication: how public knowledge fails to become organizational action. iUniverse. 
Oran, F. Ç., Güler, S. B., \& Bilir, P. (2016). İş motivasyonunun örgütsel bağlllığa olan etkisinin incelenmesi: Sultangazi/İstanbul ilköğretim okullarında bir araştırma. Mustafa Kemal Üniversitesi Sosyal Bilimler Enstitüsü Dergisi, 13(35), 236-252.

Özdoğru, M., \& Aydın, B. (2012). İlköğretim okulu öğretmenlerinin karara katılma durumları ve istekleri ile motivasyon düzeyleri arasındaki ilişki. Abant İzzet Baysal Üniversitesi Eğitim Fakültesi Dergisi, 12(2), $357-367$.

Özgan, H., \& Aslan, N. (2008). İlköğretim okul müdürlerinin sözlü iletişim biçiminin öğretmenlerin motivasyonuna etkisinin incelenmesi. Gaziantep Üniversitesi Sosyal Bilimler Dergisi, 7(1), 190-206.

Özkan, G. (2013). Çağrı merkezlerinde duygusal emek ve örgütsel iletişim. Selçuk İletişsim Dergisi, 7(4), 64-80.

Park, S. M., \& Rainey, H. G. (2012). Work motivation and social communication among public managers. The International Journal of Human Resource Management, 23(13), 2630-2660. https://doi.org/10.1080/09585192.2011.637060

Skaalvik, E. M., \& Skaalvik, S. (2018). Job demands and job resources as predictors of teacher motivation and well-being. Social Psychology of Education, 21(5), 1251-1275. https://doi.org/10.1007/s11218-018-9464-8

Tanrıverdi, S. (2007). Katılımcı okul kültürünün yabancı dil öğretmenlerinin iş motivasyonuyla ilişkisine yönelik örnek bir çalışma. Yayımlanmamış Yüksek Lisans Tezi, Yeditepe Üniversitesi Sosyal Bilimler Enstitüsü, İstanbul.

Tentama, F., \& Pranungsari, D. (2016). The roles of teachers' work motivation and teachers' job satisfaction in the organizational commitment in extraordinary schools. International Journal of Evaluation and Research in Education, 5(1), 39-45. https://doi.org/10.11591/ijere.v5i1.4520

Terek, E., Glušac, D., Nikolic, M., Tasic, I., \& Gligorovic, B. (2015). The impact of leadership on the communication satisfaction of primary school teachers in Serbia. Educational Sciences: Theory and Practice, 15(1), 73-84. https://doi.org/10.12738/estp.2015.1.2511

Timuroğlu, M. K., \& Balkaya, E. (2016). Örgütsel iletişim ve motivasyon ilişkisi-bir uygulama. International Journal of Social Inquiry, 9(2), 89-113.

Uslu, B., \& Balc1, E. (2012). Relationship between primary school teachers' organizational citizenship behaviors and organizational communication perceptions. Educational Administration: Theory and Practice, 18(3), 461-489.

Yldiz, K. (2013). Analysis of the relation of teachers' organizational identification and organizational communication. Educational Sciences: Theory and Practice, 13(1), 264-272.

Yoo, J. J., Flaherty, K., \& Frankwick, G. L. (2014). The effect of communication practice on deviance among Korean salespeople: The mediating role of intrinsic motivation. Journal of Business Research, 67(9), 19911999. https://doi.org/10.1016/j.jbusres.2013.10.012

Yüksel, İ. (2005). İletişimin iş tatmini üzerindeki etkileri: Bir işletmede yapılan görgül çalışma. Doğuş Üniversitesi Dergisi, 6(2), 291-306. https://doi.org/10.31671/dogus.2019.279

\section{Copyrights}

Copyright for this article is retained by the author, with first publication rights granted to the journal.

This is an open-access article distributed under the terms and conditions of the Creative Commons Attribution license (http://creativecommons.org/licenses/by/4.0/). 